\title{
Comments to Westaway and Bridgland - 'Causes, consequences and chronology of large-magnitude palaeoflows in Middle and Late Pleistocene river systems of northwest Europe'
}

\author{
Toucanne S. ${ }^{a}$, Zaragosi S. ${ }^{b}$, Eynaud F. ${ }^{b}$, Bourillet J.F. ${ }^{a}$, Lericolais G. ${ }^{a}$ \& Gibbard P.L. ${ }^{c}$ \\ ${ }^{a}$ IFREMER, Laboratoire Environnements Sédimentaires, BP70, 29280 Plouzané, France \\ ${ }^{b}$ Université Bordeaux 1, Environnements et Paléoenvironnements Océaniques (UMR CNRS 5805 \\ EPOC), Avenue des Facultés, 33405 Talence, France \\ ${ }^{c}$ Cambridge Quaternary, Department of Geography, University of Cambridge, Cambridge, CB2 3EN, \\ UK \\ *: Corresponding author : stoucann@ifremer.fr
}

\begin{abstract}
:
Westaway and Bridgland (Earth Surface Processes and Landforms 35: 1071-1094, 2010) discuss the causes, the consequences and the chronology of large-magnitude palaeoflows in Pleistocene river systems of northwest Europe. Based on their calculations, these authors suggest that the combined effects of meltwater from Alpine glaciers, rainfall, snowmelt and melting of permafrost during Heinrich Events (HEs) explain the large-magnitude discharges of the Fleuve Manche palaeoriver which punctuated the last glacial period.

This comment identifies some approximations and inconsistencies regarding (i) the timing of the last massive Fleuve Manche palaeoriver discharge and its relation to the de-glacial pattern of the BritishIrish Ice Sheet (Point 1); (ii) the palaeoclimatic conditions prevailing on land and the antagonistic forcing mechanism proposed by the authors to explain the large-magnitude palaeoflows (Point 2); (iii) Westaway and Bridgland's (2010) revised interpretation of the deep-sea records from the Bay of Biscay (Point 3); and (iv) the relationship between the offshore sedimentation since the Middle Pleistocene and the formation of the Dover Strait (Point 4). Each point is discussed.
\end{abstract}




\section{Point 1: Chronology \& land-sea correlation}

The chronology discussed, then adopted by Westaway and Bridgland (2010), for Marine Isotope Stage (MIS) 2 is controversial, particularly since their revised chronology relies on these authors' misinterpretations of the continental- and marine-based records recently published by Busschers et al. (2007) and Zaragosi et al. (2001, 2006), Auffret et al. (2002), Ménot et al. (2006), Eynaud et al. (2007), Toucanne et al. (2008, 2009a) and Penaud et al. (2009), respectively. Studies on the origin and the implications of the English Channel-floor palaeovalleys (e.g. Auffret et al. 1980; Larsonneur et al., 1982; Gibbard, 1988; Lericolais et al., 1996, 2003; Bourillet et al., 2003) prompted the investigations of deep-sea records from the northern Bay of Biscay. The latter records revealed that the last largemagnitude palaeoflow event of the Fleuve Manche, from ca $20 \mathrm{ka}$, with a maximum intensity between ca 18.3 and $17.5 \mathrm{ka}$, occurred in phase with the orbitally-induced rapid retreat of the mid-latitudinal European ice sheets and glaciers. Based on the regional chronology proposed by McCabe et al. (2007), the last large-magnitude palaeoflow of the Fleuve Manche and the subsequent steep decline in Fleuve Manche activity thus equates with the rapid retreat (i.e. the 'Cooley Point Interstadial'), then the moderate readvance (i.e. the 'Clogher Head' and 'Killard Point' stadials), centred on 17-16 ka (from <18 to >15 ka according to McCabe et al., 2007), of the Irish Sea glacier, respectively (Toucanne et al., 2008).

Based on this chronology, Westaway and Bridgland's (2010, p. 1090) correlation of the most recent high-palaeoflow phase of the Fleuve Manche with the 'Linns Interstadial', a brief, moderate retreat of the Irish Sea glacier, which falls between the 'Clogher Head' and 'Killard Point' stadials at around 17.1$16.6 \mathrm{ka}$ (McCabe et al., 2007), must be questioned. This correlation is untenable because Westaway and Bridgland (2010) bring forward the onset of the highest last Fleuve Manche discharge (18.3 ka) by ca 1.2-1.7 kyr, yet fail to present a thorough, reasoned discussion of the land-sea correlation proposed by Toucanne et al. (2008). Furthermore, Westaway and Bridgland's (2010) correlation is also untenable since it does not take into account the substantial radiocarbon dataset upon which the Fleuve Manche activity is founded (Zaragosi et al., 2001; Auffret et al., 2002; Zaragosi et al., 2006; Eynaud et al., 2007; Toucanne et al., 2008, 2009a). A precise chronostratigraphical framework for the land-sea correlation for northwest Europe is crucial for the understanding of past cryosphere-ocean interactions, particularly since the European ice-sheets and attendant glaciofluvial/fluvial discharge are known to have significantly influenced the Atlantic meridional overturning circulation (AMOC) (Peck et al., 2006; Toucanne et al., 2010; Denton et al., 2010).

\section{Point 2: Climate vs forcing mechanism}

The revised chronology adopted by Westaway and Bridgland (2010) is surprising because it places the last significant increase of Fleuve Manche activity at a time when polar conditions occurred throughout the wider North Atlantic region. As previously mentioned, Westaway and Bridgland (2010) suggest that this discharge resulted from the combined effects of glacial meltwater discharge from the Alpine glaciers, rainfall, snowmelt and the melting of permafrost. However, it is widely established that the 17-16 ka interval was characterised by severe cold, windy and arid conditions throughout Europe (e.g. Bard et al., 2000; Antoine et al., 2009). These conditions initiated a significant increase in permafrost development (e.g. Huijzer and Vandenberghe 1998; Renssen and Vandenberghe, 2003; Kasse et al., 2007), associated with southwards migration of the sea-ice cover over the North Atlantic (e.g. Eynaud et al., 2009) in response to the AMOC shutdown (McManus et al., 2004). This observation challenges the authors' invocation of warm and relatively moist conditions to explain the large-magnitude discharge. It is possible that the authors deduced these conditions from the brief retreat of the Irish Sea glacier during the 'Linns Interstadial'. However, McCabe et al. (2007) conclude that this ice-marginal fluctuation only reflected either a negative mass-balance episode of the BritishIrish Ice Sheet related to shutdown of the AMOC, or a calving-induced retreat of its marine margin. Therefore, the climatic conditions that prevailed over Europe between ca 17 and $16 \mathrm{ka}$, and also during the HE 2 interval, ca 24 ka ago (e.g. Bard et al., 2000; Antoine et al., 2009), were therefore incompatible with the causal mechanism of the Fleuve Manche activity proposed by Westaway and Bridgland (2010). This conclusion is supported by the detailed analysis of Weichselian-age soils in France, Belgium, the Netherlands and Germany which reveal a slow degradation of ice-poor permafrost at the end of the last glacial period (e.g. van Vliet-Lanoë, 2001), and especially between ca 15-13 ka (Kasse et al., 2007; Blaser et al., 2010).

\section{Point 3: The deep-sea records revised}

Westaway and Bridgland (2010, p. 1087) revise the Fleuve Manche activity over the last glacial period (i.e. MIS 4-2) through a "more detailed examination of [marine] data" published by Auffret et al. (2002) and Ménot et al. (2006), "that can now be regarded (after Toucanne et al., 2008; Toucanne et al., 
2009) as proxies for the Channel river paleoflow". Based on their re-examination of the data, the authors conclude that large-magnitude discharges of the Fleuve Manche palaeoriver punctuated each of the Heinrich Events. Since the Ménot et al. (2006) study focuses exclusively on the last $30 \mathrm{ka}$, Westaway and Bridgland (2010) probably based their assumption on Auffret et al.'s (2002) dataset. Nevertheless, since the reconstructed terrigenous fluxes (which we consider to be the only relevant proxy to discuss the Fleuve Manche-derived supplies in their dataset) fail to show significant increases during Heinrich Events (except during HE 2, ca $24 \mathrm{ka}$ ), we assume that the "subsidiary peaks" ( $\mathrm{p}$. 1087) recognised in Auffret et al. (2002) probably correspond to ice-rafted detritus depositional maxima, i.e. detrital inputs by icebergs from circum-North Atlantic ice sheets, rather than highmagnitude palaeoflows of the Fleuve Manche, as Westaway and Bridgland (2010) conclude. Moreover, although Toucanne et al. (2008) describe some moderate increases in sediment supply off the Fleuve Manche palaeoriver at the time of the HE 3 (ca $31 \mathrm{ka}$ ) and HE 2 (ca $24 \mathrm{ka}$ ), sediment-flux reconstructions (Auffret et al., 2002; Zaragosi et al., 2006; Toucanne et al., 2008; 2009a), palynological studies (Zaragosi et al., 2001; Eynaud et al., 2007; Penaud et al., 2009) and BIT-index analysis (Ménot et al., 2006) clearly demonstrate that the contemporaneous Fleuve Manche discharge was not of high-magnitude, contrary to that suggested by Westaway and Bridgland (2010), and was in no way comparable in scale to that occurring later. Recent quantitative analysis supports this assumption, showing a Fleuve Manche sediment load of ca $30 \cdot 10^{6}$ and $130 \cdot 10^{6} \mathrm{t} \mathrm{yr}^{-1}$ at around 24 and $18 \mathrm{ka}$, respectively (Toucanne et al., 2010).

From a methodological point of view, the time-to-time comparison of "peaks of Channel River palaeoflow" proposed by Westaway and Bridgland (2010, p. 1089) for the last glacial intervals is also debatable. Based on "the data reported by Toucanne et al. (2009)", the authors argue that the "peak Channel River palaeoflow during MIS 8 [10] was 70\% [ 40\%] of its peak in MIS 2". Firstly, these quantitative comparisons are made without any supporting analysis or evidence. Secondly, if these comparisons are based on the terrigenous flux reconstruction proposed by Toucanne et al. (2009a), they are debatable : only a comparison of terrigenous flux reconstructed for a similar time period from a uniform chronostratigraphical framework, i.e. "peaks" reconstructed using identical chronological tiepoints, can be considered as quantitative (e.g. Figure 6, based on Figure 3, in Toucanne et al. (2009a)). This constraint, difficult to apply to a set of long marine records, leads therefore the (nonquantitative) time-to-time comparison of Fleuve Manche discharges throughout geological time to be based on a multi-proxy approach, itself to be compared to palaeoenvironmental reconstructions from regional to global scales (e.g. Eynaud et al., 2007; Penaud et al., 2009; Toucanne et al., 2009a, 2009b). Regarding this latter point, it is curious, in the light of the accumulating continental-based reconstructions indicating a glaciated North Sea around the Last Glacial Maximum (Bradwell et al., 2008; Sejrup et al., 2009; Clarke et al., in press among others), that Westaway and Bridgland (2010) omit potential ice-forcing from their calculations.

\section{Point 4: The megaflood hypothesis and the deep-sea sedimentation in the Bay of Biscay}

Finally, we dispute the apparent contradiction, highlighted by Westaway and Bridgland (2010), between the Fleuve Manche reconstructions proposed by Toucanne et al. (2009a) and the 'megaflood hypothesis' presented by Gupta et al. (2007), implicit in which is the instantaneous formation of the present-day English Channel palaeovalleys at an indefinite time. Toucanne et al. (2009a) demonstrates many episodic, potentially seasonal, massive discharges during each of the last four glacial intervals, from MIS 10 (which occurs at the bottom of the core, but implicitly not the base of the sequence) to MIS 2. The sedimentological analysis of the deep-sea records off the Fleuve Manche reveals, considering that the Hurd Deep (e.g. Lericolais et al., 1996) did not act as a significant sediment trap between the European lowlands and the Bay of Biscay after the Middle Pleistocene, that the highest magnitude palaeoflows recorded since MIS 10, dating from ca $155 \mathrm{ka}$ (MIS 6) and ca 20-18 ka (MIS 2), were not catastrophic in character. This demonstrates: $(I)$ that the expected megaflood must predate MIS 10 (as partially confirmed by Toucanne et al., 2009b), and (ii) that the high-magnitude palaeoflows noted above exploited the inherited Channel (Manche)-floor morphology. Contrary to the claim by Westaway and Bridgland (2010, p. 1089), Gupta et al. (2007) propose a MIS 12-6 age for the expected catastrophic flood, and neither Toucanne et al. (2008) nor Toucanne et al. (2009a) suggest that this flood "caused the offshore sedimentation during -18-17 ka".

\section{Conclusions}

Westaway and Bridgland's (2010) study, and particularly its focus on the causes of the high-magnitude Fleuve Manche palaeoflows, is based on a continental approach which is complementary to those developed from the offshore evidence. This approach is crucial and would contribute to a higher level 
of understanding. Nevertheless, although Westaway and Bridgland (2010) raise some relevant questions regarding the contributions of snowmelt or melting permafrost to the sediment transfers from the land to the deep-sea, their approximations and inconsistencies, identified here, strongly undermine their conclusions. By attempting to reinterpret the marine records from the Bay of Biscay and the attendant chronology without assessing all the available evidence, Westaway and Bridgland (2010) place the large-magnitude palaeoflows of the Fleuve Manche during intervals when the prevailing climatic conditions could not have supported the causal mechanism invoked by these authors. Numerical modelling, on which Westaway and Bridgland (2010) based a significant proportion of their study, has its place in hypothesis testing. However, it must retain a supporting role, rather than leading the reconstruction of geological history and landscape evolution based on direct observation in the field or the laboratory.

\section{References}

Antoine P, Rousseau DD, Moine O, Kunesch S, Hatté C, Lang A, Tissoux H, Zöller L. 2009. Rapid and cyclic aeolian deposition during the Last Glacial in European loess : a high-resolution record from Nussloch, Germany. Quaternary Science Reviews 28: 2955-2973.

Auffret JP, Larsonneur C, Smith AJ. 1980. Cartographie du réseau des paléovallées et de l'épaisseur des formations superficielles meubles de la Manche orientale. Annales de l'Institut océanographique 56: 21-35.

Auffret G, Zaragosi S, Dennielou B, Cortijo E, Van Rooij D, Grousset F, Pujol C, Eynaud F, Siegert M. 2002. Terrigenous fluxes at the Celtic margin during the last glacial cycle. Marine Geology 188: 79108.

Bard E, Rostek F, Turon JL, Gendreau S. 2000. Hydrological impact of Heinrich events in the subtropical Northeast Atlantic. Science 289: 1321-1324.

Blaser PC, Kipfer R, Loosli HH, Walraevens K, Van Camp M, Aeschbach-Hertig W. 2010. A 40 ka record of temperature and permafrost conditions in northwestern Europe from noble gases in the Ledo-Paniselian Aquifer (Belgium). Journal of Quaternary Science 25: 1038-1044.

Bourillet JF, Reynaud JY, Baltzer A, Zaragosi S. 2003. The "Fleuve Manche": the submarine sedimentary features from the outer shelf to the deep-sea fans. Journal of Quaternary Science 18: 261-282.

Bradwell T, Stoker MS, Golledge NR, Wilson CK, Merritt JW, Long D, Everest JD, Hestvik OB, Stevenson, AG, Hubbard, AL, Finlayson, AG, Mathers, HE. 2008. The northern sector of the last British Ice Sheet: Maximum extent and demise. Earth-Science Reviews 88: 207-226.

Busschers FS, Kasse C, Van Balen RT, Vandenberghe J, Cohen KM, Weerts HJ, Wallinga J, Johns C, Cleveringa P, Bunnik FPM. 2007. Late Pleistocene evolution of the Rhine-Meuse system in the southern North-Sea Basin: Imprints of climate change, sea-level oscillation and glacio-isostacy. Quaternary Science Reviews 26: 3216-3248.

Clark CD, Hughes ALC, Greenwood SL, Jordan C, Sejrup HS. in press. Pattern and timing of retreat of the last British-Irish Ice Sheet. Quaternary Science Reviews, doi:10.1016/j.quascirev.2010.07.019.

Denton GH, Anderson RF, Toggweiler JR, Edwards RL, Schaefer JM, Putnam AE. 2010. The last glacial termination. Science 328: 1652-1656.

Eynaud F, De Abreu L, Voelker A, Schonfeld J, Salgueiro E, Turon JL, Penaud A, Toucanne S, Naughton F, Sanchez-Goni MF, Malaize B, Cacho I. 2009. Position of the Polar Front along the western Iberian margin during key cold episodes of the last $45 \mathrm{ka}$. Geochemistry, Geophysics, Geosystems 10: Q07U05, doi:10.1029/2009GC002398.

Eynaud F, Zaragosi S, Scourse JD, Mojtahid M, Bourillet JF, Hall IR, Penaud A, Locascio M, Reijonen A. 2007. Deglacial laminated facies on the NW European continental margin: the hydrographic 
significance of British Ice sheet deglaciation and Fleuve Manche paleoriver discharges. Geochemistry, Geophysics, Geosystems 8: doi:10.1029/2006GC001496.

Gibbard PL. 1988. The history of great northwest European rivers during the past three millions years. Phil. Trans. R. Soc. Lond. B318: 559-602.

Gupta S, Collier JS, Palmer-Felgate A, Potter G. 2007. Catastrophic flooding origin of shelf valley systems in the English Channel. Nature 448: 342-345.

Huijzer B. and Vandenberghe J. 1998. Climatic reconstruction of the Weichselian Pleniglacial in northwestern and central Europe. Journal of Quaternary Science 13: 391-417.

Kasse C, Vandenberghe J, De Corte F, Van den Haute P. 2007. Late Weichselian fluvio-aeolian sands and coversands of the type locality Grubbenvorst (southern Netherlands): sedimentary environments, climate record and age. Journal of Quaternary Science 22: 695-708.

Lericolais, G, Auffret JP, Bourillet JF. 2003. The Quaternary Channel River: seismic stratigraphy of its palaeo-valleys and deeps. Journal of Quaternary Science 18: 245-260.

Lericolais G, Guennoc P, Auffret JP, Bourillet JF, Berné S. 1996. Detailed survey of the western end of the Hurd Deep (English Channel): new facts for a tectonic origin. In Geology of Siliciclastic Shelf Seas, De Batist, M., Jacobs, P. (Eds). Special publication, Geological Society, London, pp. 203-215.

McCabe AM, Clark PU, Clark J, Dunlop P. 2007. Radiocarbon constraints on readvances of the British-Irish Ice Sheet in the northern Irish Sea Basin during the last deglaciation. Quaternary Science Reviews 26: 1204-1211.

McManus JF, Francois R, Gherardi JM, Kelgwin L, Drown-Leger S. 2004. Collapse and rapid resumption of Atlantic meridional circulation linked to deglacial climate changes. Nature 428: 834-837.

Ménot G, Bard E, Rostek F, Weijers JWH., Hopmans EC, Schouten S, Sinninghe Damsté JS. 2006. Early reactivation of European Rivers during the last deglaciation. Science 313: 1623-1625.

Penaud A, Eynaud F, Turon JL, Zaragosi S, Malaizé B, Toucanne S, Bourillet JF. 2009. What forced the European ice-sheets history during the last two glacial stages (MIS 6 and MIS 2)? Palynological evidences. Palaeogeography, Palaeoclimatology, Palaeoecology 281: 66-78.

Peck VL, Hall IR, Zahn R, Elderfield H, Grousset F., Hemming SR, Scourse JD. 2006. High resolution evidence for linkages between NW European ice sheet instability and Atlantic Meridional Overturning Circulation. Earth and Planetary Science Letters 243: 476-488.

Renssen $\mathrm{H}$, Vandenberghe J. 2003. Investigation of the relationship between permafrost distribution in NW Europe and extensive winter sea-ice cover in the North Atlantic Ocean during the cold phases of the Last Glaciation. Quaternary Science Reviews 22: 209-223.

Sejrup HP, Nygård A, Hall AM, Haflidason H. 2009. Middle and Late Weichselian (Devensian) glaciation history of south-western Norway, North Sea and eastern UK. Quaternary Science Reviews 28: $370-380$.

Toucanne S, Zaragosi S, Bourillet JF, Cremer M, Eynaud F, Turon JL, Fontanier C, Van Vliet Lanoë B, Gibbard PL. 2009a. Timing of massive 'Fleuve Manche' discharges over the last 350 kyr: insights into the European Ice Sheet oscillations and the European drainage network from MIS 10 to 2. Quaternary Science Reviews 28: 1238-1256.

Toucanne S, Zaragosi S, Bourillet JF, Gibbard PL, Eynaud F, Giraudeau J, Turon JL, Cremer M, Cortijo E, Martinez P, Rossignol L. 2009b. A 1.2 My record of glaciation and fluvial discharges from the West European Atlantic margin. Quaternary Science Reviews 28: 2974-2981.

Toucanne S, Zaragosi S, Bourillet JF, Marieu V, Cremer M, Kageyama M, Van Vliet Lanoë B, Eynaud F, Turon JL, Gibbard, PL. 2010. The first estimation of Fleuve Manche palaeoriver discharge during 
the last deglaciation: Evidence for Fennoscandian ice sheet meltwater flow in the English Channel ca 20-18 ka ago. Earth and Planetary Science Letters 290: 459-473.

Toucanne S, Zaragosi S, Bourillet JF, Naughton F, Cremer M, Eynaud F, Dennielou B. 2008. Activity of the turbidite levees of the Celtic-armorican margin (Bay of Biscay) during the last 30,000 years: Imprints of the last European deglaciation and Heinrich events. Marine Geology 247: 84-103.

Van Vliet-Lanoë B. 2001. Soil thermal contraction in NW Europe related to the dynamics of the Weichselian ice sheet. Comptes Rendus de l'Academie des Sciences - Series IIA - Earth and Planetary Science 322: 461-468.

Westaway R, Bridgland DR. 2010. Causes, consequences and chronology of marge-magnitude palaeoflows in Middle ands Late Pleistocene river systems of northwest Europe. Earth Surface Processes and Landforms 35:1071-1094.

Zaragosi S, Eynaud F, Pujol C, Auffret G, Turon JL, Garlan T. 2001. Initiation of the European deglaciation as recorded in the northwestern Bay of Biscay slope environments (Meriadzek Terrace and Trevelyan Escarpment): a multi-proxy approach. Earth and Planetary Science Letters 188: 493507.

Zaragosi S, Bourillet JF, Eynaud F, Toucanne S, Denhard B, Van Toer A, Lanfumey V. 2006. The impact of the last European deglaciation on the deep-sea turbidite systems of the Celtic-Armorican margin (Bay of Biscay). Geo-Marine Letters 26: 317-329. 